\title{
Assessing the Impact of Private Sector Credit on Economic Performance: Evidence from Sectoral Panel Data for Kenya
}

\author{
Maureen Were (Corresponding author) \\ Research Centre/ Research Department, Central Bank of Kenya \\ P.O. Box 60000 - 00200 Nairobi, Kenya \\ Tel: 254-20-286-0000Ｅ-mail: sikalimw@centralbank.go.ke \\ Joseph Nzomoi \\ Research Centre, Central Bank of Kenya \\ P.O. Box 60000 - 00200 Nairobi, Kenya \\ Tel: 254-20-286-0000 E-mail: nzomoijn@ksms.or.ke \\ Nelson Rutto \\ Research Department, Central Bank of Kenya \\ P.O. Box 60000 - 00200 Nairobi, Kenya \\ Tel: 254-20-286-0000Ｅ-mail: ruttonk@centralbank.go.ke
}

Received: December 11, 2011

doi:10.5539/ijef.v4n3p182

\author{
Accepted: January 5, 2012 \\ Published: March 1, 2012 \\ URL: http://dx.doi.org/10.5539/ijef.v4n3p182
}

We are grateful to Prof. Alemayehu Geda, researchers at the Research Department of Central Bank of Kenya and the anonymous referee for their useful comments on earlier versions of this paper. The views expressed in this paper are those of the authors and should not be misconstrued to be synonymous with those of the institution they work for.

\begin{abstract}
Despite the growing literature on financial development-economic growth nexus, there is paucity of empirical studies that explore the impact of access to credit and economic performance at the sectoral country level, as an increasing number of studies largely focus on cross-country analyses. This paper investigates the impact of access to bank credit on the economic performance of key economic sectors using sectoral panel data for Kenya. We find a positive and significant impact of credit on sectoral gross domestic product measured as real value added. However, the magnitude of the impact is smaller once factors such as the labour employed and past economic performance of the sectors are taken into account. Policies aimed at financial sector deepening and increasing access to credit are of essence to enhancing economic performance. Such policies should, however, be complemented with strategies that enhance efficiency of the key sectors of economy.
\end{abstract}

Keywords: Credit, Economic performance, Economic sectors, Finance, Growth

\section{Introduction}

The role of financial sector in promoting economic growth is well acknowledged, dating back to the early economists like Schumpeter (1911) who strongly argued in support of finance-led growth. Financial sector plays a key role in channelling savings into productive investment, especially in the formal sectors of the economy. The banking sector in particular is well recognised as a key conduit for financial intermediation in the economy. Access to credit enhances the productive capacity of businesses. Businesses and enterprises with adequate financial access have greater potential to grow. Studies have shown that a number of business enterprises in Africa, particularly the small and medium manufacturing firms are credit-constrained (Bigsten et al., 2000; Loening et al., 2008; Soderbom, 2000).

Although the literature regarding the role of financial development on economic growth has grown rapidly in recent times, studies that examine bank credit or access to private sector credit and how it impacts on the economic 
performance of industries or economic sectors (Note 1) have been overshadowed by the increasing number of empirical studies that largely focus on financial development and growth at the cross-country levels. In a survey of recent literature on finance and growth, Ang (2008) observes that although these studies have contributed to the understanding of finance-growth nexus, the results are subject to a number of criticisms, such as failure to account for the significant differences among countries and hence, points to the need for country-specific studies to inform the policy debate. Moreover, whereas broad measures such as broad money (to Gross Domestic Product (GDP)) are often used as a proxy of financial development, they can conceal the real effects of finance on growth since not all the money is channelled or used for investment. That notwithstanding, most studies provide evidence of a positive effect of finance or financial market development on economic growth (Jayaratne and Strahan 1996; Rajan and Zingales 1998; Guiso et al., 2004; King and Levin 1993). King and Levin (1993) for example, find a positive effect of finance on economic growth based on cross country growth regressions using data for 77 countries. However, a re-examination by Favara (2003) of the analysis by Levine, Loayza and Beck (2000) indicate a weak effect at best. Using time series analysis, Hondroyiannis et al (2005) find a bilateral causal relationship between financial development and economic growth for Greece. The recent work of Demirguc-Kunt and Levin (2008) in a review of the various analytical methods used in finance literature found strong evidence that financial development is important for growth. Lately, empirical work linking banking sector developments to real activity using indicators such as bank credit has started growing out of the broad literature documenting the relationship between financial development and economic growth (see Beck and Levine (2001) for instance). In attempt to improve upon measurements used in cross-country studies on finance and growth, Beck and Levine (2001) measure bank development as bank credit to private sector divided by GDP. For a detailed review of literature on finance and economic growth, see Trew (2006) and Ang (2008). This paper takes a digression from cross-country studies by using Kenya as a case study to examine the impact of bank credit on the economic performance of key sectors of the economy, i.e. sectoral GDP measured as real value added. The sectors include agriculture, manufacturing, building and construction, transport and communication, wholesale and retail trade and hotels and restaurants. Although Kenya's vision of becoming "a globally competitive and prosperous country" by 2030 is pegged on the economic success of these sectors (Republic of Kenya 2007), one of the constraints to sectoral growth has been hailed to be inadequate access to credit. Credit provision is, thus, expected to play a role as the country forges forward with the realization of its development objectives.

\section{An Overview of the Banking Structure and Trends in Bank Credit to Private Sector}

\subsection{Structure of the Banking Sector}

A significant portion of credit in Kenya is extended through the banking system, though there are some other institutions such as savings and credit cooperative societies, finance companies and micro finance institutions that provide credit, mainly targeting small and micro enterprises. However, availability of data for the latter is very limited. The rest of this section explores the developments in Kenya's banking sector.

The banking sector is made up of 44 institutions comprising of 42 commercial banks, 2 mortgage finance companies. In terms of ownership, about 79.5 percent are locally owned while the rest are foreign owned. In 2010, the total net assets for local private institutions constituted 54.7 percent while the local public institutions and foreign institutions constituted 5.3 percent and 40.0 percent of the total assets, respectively.

The banking sector recorded an impressive growth in tandem with improved economic activity after 2003, with return on assets of 3.6 percent in 2010 from 0.5 percent in 2000 (Table I). The improvement in profitability was attributed to an increase in income streams, boosted by the increase in the level of economic activities. This was coupled with the decline in the industry's stock of non-performing loans. The banking sector is one of the few sectors that remained resilient to the effects of the post-December 2007 general election violence and the global financial crisis, registering annualised profit after tax to average asset ratios (profitability ratios) of 2.8 percent, 2.9 percent and 3.6 percent in 2008, 2009 and 2010, respectively. However, the distribution of profits remained skewed with four major banks accounting for over 60 percent of the total pre-tax profits in the industry.

Insert Table 1 Here

On the other hand, growth in private sector credit from the banking sector declined from 26.7 percent in the year to December 2008 to 13.9 percent in 2009 but rose in 2010 to 20.3 percent. Asset quality as measured by the ratio of net non-performing loans to gross loans improved from 9.2 percent in December 2008 to 6.3 percent in 2010.

In terms of capital, the banking sector is well capitalized, mainly on account of fresh capital injection and retention of profits. Capital adequacy in the sector, as well as liquidity has been strong for most of the years. The high liquidity is a reflection of the sector's preference for liquid assets notably risk free government securities. The commercial banks maintained an average liquidity ratio of 51 percent in 2010, way above the minimum requirement 
of 20 percent. Holding other factors constant, the banking sector is therefore, well placed to provide sufficient credit to spur economic growth.

\subsection{Trends in Bank Credit to the Private Sector}

There has been a significant rise in bank credit to the private sector relative to public sector credit, particularly since 2003 (see Figure I). The proportion of private sector credit relative to public sector credit increased particularly since 2003 . For instance, private sector accounted for 80 percent and 76.5 percent of total credit in 2008 and 2009, respectively. A further decomposition of private sector credit into credit for businesses (private enterprises) and private households shows that the later has increased rapidly (from 3 percent in 1997-1999 to 13 percent of total private sector credit in 2009), mainly on account of stiff competition within the industry that saw an expansion of a range of credit products including personal unsecured loans. That notwithstanding, at 27 percent of GDP, bank credit to the private sector still remain relatively low by international standards. Holding other factors constant, there is still potential for credit growth.

\section{Insert Figure 1 Here}

In terms of sectoral allocations, manufacturing sector and the service sector (wholesale and retail trade, restaurants and hotels) accounts for the highest proportion of credit as a percentage of bank credit to the overall private sector, respectively. On the average, the two sectors accounted for a third of the private sector credit in the period 2000-2003 before declining to about 26 percent in 2007-2009. The share of private sector credit to agriculture declined significantly in 2008 following the effects of the post general election violence that adversely affected the agricultural sector. Credit to transport and communication sector has been on the rise mainly on the account of increased infrastructure and construction activities.

\section{Theoretical Framework and Model Specification}

The endogenous growth literature underscores the role of finance in promoting long run economic growth and hence, provides a good starting ground for analysing and understanding the impact of credit on economic performance. The usual two factor neoclassical growth model developed by Solow $(1956,1957)$ and others is extended by incorporating the role of credit. In the finance-growth literature, financial sector services such as credit availability influence economic growth through their impact on capital accumulation and technological innovation (see Levine 1997, Trew 2006). Mackinnon (1973) long argued that whereas a farmer could provide own savings to increase the usage of commercial fertilizer, it was a virtual impossibility of a poor farmer financing from current savings, the total amount needed for investment in order to adopt the new technology. Greenwood and Jovanovich (1990) observe that financial institutions produce better information, improve resource allocation (through financing firms with the best technology) and thereby induce growth. It has also been argued that financial institutions like the banking sector are much better placed to evaluate prospective entrepreneurs and hence, likely to finance the promising ones thereby increasing the probability of successful innovation which accelerate economic growth (King and Levine, 1993).

Assuming a Cobb-Douglas production function

$$
Q_{i t}=A^{\lambda} K_{i t}^{\alpha} L_{i t}^{\beta}
$$

where $\mathrm{Q}_{\mathrm{it}}=$ real output for industry $\mathrm{i}$ at time $\mathrm{t} ; K_{i t}=$ capital stock for industry $\mathrm{i}$, time t $; L_{i t}=$ units of labour utilized by industry $\mathrm{i}$ at time $\mathrm{t} ; \alpha, \beta$ represent the factor share coefficients whereas $\lambda$ allows for factors changing the efficiency of the production process. We assume that the technical efficiency of the production process is correlated with availability of credit, implying that the parameter $\mathrm{A}$ in the production function varies with credit access. Access to credit help boost the rate of technological innovation and hence output (Trew 2006). In other words, credit constraints limit business expansion and can constrain production processes to economically inefficient scales.

From the foundations of profit-maximization, a firm or industry will employ labour and capital such that the marginal revenue product of labour $\left(\mathrm{MRP}_{\mathrm{L}}\right)$ equals the wage $(w)$ and the marginal revenue product of capital $\left(\mathrm{MRP}_{\mathrm{K}}\right)$ equals the user cost $(c)$. Marginal products of labour and capital are derived by differentiating equation (1) with respect to labour and capital respectively. These are then multiplied by unit price (p) to obtain $M R P_{L}$ and $M R P_{K}$ as below

$$
\begin{aligned}
& M R P_{L}=p \beta A^{\lambda} K^{\alpha} L^{\mathrm{B}-1}=w \\
& M R P_{K}=p \alpha A^{\lambda} K^{\alpha-1} L^{\beta}=c
\end{aligned}
$$

Solving this system simultaneously for $\mathrm{K}$ allows us to eliminate capital from the expression for output in equation (1). The resultant expression is given below as 


$$
Q_{i t}=A^{\lambda}\left(\frac{\alpha L_{i t}}{\beta} \frac{w}{c}\right)^{\alpha} L_{i t}^{\beta}
$$

By taking logarithms we obtain

$$
\ln Q_{i t}=\theta_{0}+\theta_{1} \ln A+\theta_{2} \ln L_{i t}
$$

where

$$
\theta_{0}=\alpha\left(\ln \left(\frac{\alpha}{\beta}\right)+\ln \left(\frac{w}{c}\right)\right)
$$

$$
\begin{gathered}
\theta_{1}=\lambda \\
\theta_{2}=\alpha+\beta
\end{gathered}
$$

A is assumed to vary with credit accessed. Letting credit to be denoted by CRDT, the basic estimable equation is specified below (Note 2)

$$
\ln Q_{i t}=\phi_{0}+\phi_{1} \ln L_{i t}+\phi_{2} \ln C R D T+\phi_{3} R_{t}+S_{i}+\varepsilon_{i t}
$$

Where $Q_{\mathrm{it}}=$ real output measured as value added (real GDP) of sector or industry $i$ in year $t, \mathrm{~L}_{\mathrm{it}}=$ employment, i.e. labour employed by sector $i$, year $t, \mathrm{~S}_{\mathrm{i}}=$ sector-specific effects capturing the impact of unobservable effects, while $\mathrm{R}=$ real interest rate (i.e. lending rate) at time $\mathrm{t}$, which is included to capture constraints to borrowing. It is time-specific but same for all sectors. $\varepsilon_{i t}$ is the error term. In an empirical analysis of the impact of agriculture credit on economic growth in Nigeria, Enoma (2010) finds credit and interest rate to be some of the important factors in influencing economic growth in Nigeria. We also control for labour as a fundamental factor of production particularly in the Kenyan context where most of the entrepreneurial or production activities such as agricultural production are labour intensive. Credit is measured in real terms. All variables are in natural logarithms except the interest rate. We expect a positive impact of private sector credit and labour on real sectoral GDP and a negative effect with respect to interest rate. The cross sections constitute seven sectors which account for over 60 percent of the GDP, out of which agriculture contributes about 25 percent of the GDP (Note 3). The time series are for the period 1998 to 2010 .

\section{Methodology}

To assess the impact of credit accessed by different economic sectors on their economic performance, we employ panel data estimation methodology. The oft-touted power of panel data derives from their theoretical ability to isolate the effects of specific actions, treatments, or more general policies (Hsiao 2003). Ignoring the time-specific or sector-specific unobserved (omitted) effects that exist among sectors in the conventional time series and cross-sectional studies on financial development and economic growth leads to biased or misleading results. The basic assumption of the fixed and random effects models is that, conditional on the observed explanatory variables, the effects of omitted (excluded) variables are driven by (1) individual time-invariant such as individual-industry management style and ability, efficiency, or other technical differences between sectors; (2) period individual-invariant - variables that are same for all firms at a given time but that vary through time. These are variables that reflect general conditions affecting the productivity of all sectors but that are fluctuating over time (such as weather in agriculture production). The third class is individual time-varying. Ideally, such sector-specific and time-effects variables should be explicitly introduced into the equation or specification.

The central assumption of random effects model is that the sector-specific effects (random effects) are uncorrelated with the explanatory variables. This assumption is tested using Hausman test. The fixed-effects estimates are calculated from differences within each sector across time. We also note that in most economies especially African economies, past or previous performance tends to influence current economic performance. Hence, for robustness, we also estimated a dynamic panel model with lagged dependent variable using Generalised Method of Moments (GMM) albeit keeping in mind the limited size of the sample. GMM is best suited in dealing with the endogeneity issues and is convenient for estimating extensions of the basic unobserved effects model (Wooldridge 2001).

\section{Empirical Results and Discussion}

To assess the impact of credit, we start with a simple, basic model with credit accessed as the only explanatory variable (model 1). In model 2, we control for labour (employment level) in each sector and in model 3, interest rate is added. One-way error component model regression results for both fixed effects and random effects as well as the GMM results (model 4) are reported in Table 2. In model 3a, we report the results for Seemingly Unrelated Regression (SUR) fixed effects model, which allow for contemporaneous effects between the sectors (i.e. the error terms are assumed to be contemporaneously correlated). This is a more intuitive case since the sectors face more or 
else similar shocks. For robustness, the two way error component model results (model 2) are also reported in Table 3. Cross-section heteroskedasticity and correlation among the variables are common problems in panel data. To ensure validity of results, the reported results were obtained by estimating a feasible generalised least squares specification correcting for both cross-section heteroskedasticity and contemporaneous correlation where possible.

Insert Table 2 Here

The empirical results (both random and fixed effects models) indicate that access to credit has a statistically significant and positive impact on sectoral GDP. However, the magnitude of the impact is reduced from 0.30 to 0.19 when we control for labour employed. We further observe that when we control for the influence previous economic performance has on current performance using GMM, the impact of credit is statistically significant but drastically reduced (0.04). Nonetheless, the findings support the positive impact of credit on economic performance often reported in the literature (Abu-Bader and Abu-Qarn 2008; Rajan and Zingales 1998; Guiso et al., 2004 among others), though the impact is smaller. The other variables have the expected signs though the labour variable turned out to be insignificant when real interest rate was added while at the same time controlling for heteroskedasticity. However, the fixed effects SUR model (model 3a) which intuitively captures the effects of correlation between sectors shows all the variables as being highly significant.

Since the cross-sections (sectors) are few, we also reported the fixed effects. In all cases, the results consistently show that there are some unobserved or excluded factors that enhance the effect of credit on economic performance in agriculture, manufacturing, transport and communication and service (wholesale and retail trade, hotels and restaurants) sectors. These could be the quality of managerial or technological skills or other factors that enhance efficiency in those sectors. Agricultural sector accounts for a quarter of the GDP followed by manufacturing sector. The performance of these sectors is thus critical to the performance of the entire economy. On the other hand, there are certain factors associated with building and construction, electricity and water and mining and quarrying that inhibit the economic performance. The F-test statistic for validity of the fixed effects model was found to be highly significant implying the fixed effects model is valid. The Hausman test was also undertaken but was not highly significant - the validity of Hausman test in small samples is however questionable.

The results of the two-way error component model allowing the unobservable effects to vary both across sectors and time period (fixed effects model) or be random across sectors and periods (random effects) as reported in Table 3 corroborate the results reported above. The impact of credit is positive and significant (Note 4). Additionally, period fixed effects shows that there are certain factors or measures undertaken, which consistently enhanced economic performance over time, particularly in the period from 2005 to 2010. This relates to the period that saw a number of policy strategies and reforms in revamping economic growth after the National Rainbow Coalition (NARC) government came into power in 2004. These included economic, institutional and governance reforms aimed at enhancing productivity to spur growth.

Insert Table 3 here

\section{Conclusion and Policy Implications}

Despite the growing literature on financial development and economic growth, empirical studies that divulge into how access to bank credit impacts economic growth at the country or sectoral level are scant. Using sectoral panel data, the paper makes a contribution by investigating the relationship between access to credit and sectoral economic performance (i.e. sectoral GDP) in Kenya. In particular, we employ panel data estimation, specifically the fixed-effects approach to capture sector-specific effects, which if correlated with the explanatory variables, can lead to inconsistent or misleading estimates. Failure to control for fixed effects in purely time series-based studies can lead to biased or misleading results.

In general, there has been a rise in bank credit to private sector in the recent past. More importantly, the empirical results show a positive impact of credit on sectoral GDP, consistent with other findings in the literature. However, the magnitude of the impact is smaller when other factors such as labour and past economic performance of the sectors are controlled for. The fixed effects model also shows that there some unobserved factors that enhance economic performance of key sectors such as agriculture, manufacturing, transport and communication and service sectors.

Overall, provision of private sector credit to key economic sectors of the economy holds great potential to promoting sectoral economic growth. The banking sector, which is the main source of credit to the private sector, is an important channel of financial intermediation through which financial resources can be mobilised for productive investment needed for the realisation of the high economic growth path envisaged under vision 2030. Consequently, policies towards deepening of the financial sector and reducing the cost of credit which is currently considered to be 
high are important (Note 5). Such policies should, however, be accompanied with other complementary strategies that enhance productivity and consequently growth of key sectors of economy such as manufacturing and agriculture.

\section{References}

Abu-Bader, S., \& Abu-Qarn, A.S. (2008). Financial Development and Economic Growth: The Egyptian Experience. Journal of Policy Modeling, 30, 887-898. http://dx.doi.org/10.1016/j.jpolmod.2007.02.001

Ang, J.B. (2008). A Survey of Recent Developments in the Literature of Finance and Growth. Journal of Economic Surveys, 22(3), 536-576. http://dx.doi.org/10.1111/j.1467-6419.2007.00542.x

Beck, T., \& Levine, R. (2001). Stock Markets, Banks and Growth: Correlation or Causality. Washington: The World Bank.

Bigsten, A., Collier, P., Dercon, S., Fafchamps, M., Gauthier, B., Gunning, J., Soderbom, M., Oduro, A., Oostendorp, R., Pattillo, C., Teal, F., \& Zeufack A. (2000). CSAE Working Paper Series No. 2000-24, Center for the Study of African Economies, University of Oxford.

Demirguc-Kunt, A., \& Levine R. (2008). Finance, Financial Sector Policies and Long- Run Growth. World Bank Policy Research Working Paper 4469, World Bank.

Enoma, A. (2010). Agricultural Credit and Economic growth in Nigeria: An empirical Analysis. Business and Economics Journal, 14, 1-7.

Favara, G. (2003). An Empirical Reassessment of the Relationship between Finance and Growth. IMF Working paper 03/123, IMF.

Greenwood, J., \& Jovanovich, B. (1990). Financial Development, Growth and the Distribution of Income. Journal of Political Economy, 98, 1076-1107.

The Role of Social Capital in Financial Development. American Economic Review, 94(3), 526-556. http://dx.doi.org/10.1257/0002828041464498

Hondroyiannis, G., Lolos, S., \& Papapetrou, E. (2005) Financial Markets and Economic Growth in Greece, 19861999. Journal of International Financial Markets, Institutions and Money, 15, 173-188. http://dx.doi.org/doi:10.1016/j.intfin.2004.03.006

Hsiao, C. (2003). Analysis of Panel Data. New York: Cambridge University Press.

Jayaratne, J., \& Strahan, P.E. (1996). The Finance-Growth Nexus: Evidence from Bank Branch Deregulation. Quarterly Journal of Economics, CXI. 639-671.

King, R.G., \& Levin, R. (1993). Finance and Growth: Schumpeter Might Be Right. Quarterly Journal of Economics, $108,717-738$.

Levine, R. (1997). Financial Development and Economic Growth: Views and Agenda. Journal of Economic Literature, XXXV, 688-726.

Levine, R., Loayza, N., \& Beck, T. (2000). Financial Intermediation and Economic Growth: Causes and Causality. Journal of Monetary Economics, 46. 31-77.

Loening, J., Rijkers, B., and Soderbom, M. (2008). Non-farm Microenterprise Performance and the Investment Climate: Evidence from Rural Ethiopia. World Bank, Policy Research Working Paper No. 4577.

McKinnon R. (1973). Money and Capital in Economic Development. Washington: The Brookings Institute.

Rajan, R., \& Zingales, L. (1998). Financial Dependence and Growth. American Economic Review, LXXXVIII. 559-586.

Republic of Kenya, (2007). Vision 2030. A Competitive and Prosperous Kenya. Nairobi: Government Printer.

Schumpeter, J.A. (1911). The Theory of Economic Development. Oxford: Oxford University Press.

Soderbom, M. (2000). Investment in African Manufacturing: A Microeconomic Analysis. Center for the Study of African Economies, Manor Road, Oxford.

Solow, R. M. (1957). Technical Change and the Aggregate Production Function. Review of Economics and Statistics, 39. 312-320.

Solow, R.M. (1956). A Contribution to the Theory of Economic Growth. Quarterly Journal of Economics, 70. 65-94. 
Trew, A. (2006). A Critical Survey. Economic Record, 82(259), 481-490. http://dx.doi.org/10.1111/j.1475-4932.2006.00361.x

Wooldridge, J.M. (2001). Applications of Generalized Method of Moments Estimation. Journal of Economic Perspectives, 15(4), 87-100.

\section{Notes}

Note 1. 'Industries' and 'sectors' are used interchangeably in the paper

Note 2. Given we are dealing with real output, w/c is eliminated from the estimable equation by assuming the wage/user cost variations across firms can sufficiently be captured by the fixed effects.

Note 3. The sectors considered were those with same classification under GDP activities, credit to private sector and sectoral employment.

Note 4. Estimation with variables in growth rates also indicated a positive impact of credit on real growth (results not reported in the paper).

Note 5. The interest rates charged on bank loans in Kenya are still considered high. According to financial sector deepening study conducted in 2006, 68.2 percent of those who had used formal providers as source of credit considered the interest rate charged on loan to be very high.

Table 1. Banking Sector Statistics

\begin{tabular}{|l|c|c|c|c|c|c|c|c|c|c|c|}
\hline & $\mathbf{2 0 0 0}$ & $\mathbf{2 0 0 1}$ & $\mathbf{2 0 0 2}$ & $\mathbf{2 0 0 3}$ & $\mathbf{2 0 0 4}$ & $\mathbf{2 0 0 5}$ & $\mathbf{2 0 0 6}$ & $\mathbf{2 0 0 7}$ & $\mathbf{2 0 0 8}$ & $\mathbf{2 0 0 9}$ & $\mathbf{2 0 1 0}$ \\
\hline Capital adequacy $^{1}$ & 17.6 & 17.9 & 17 & 17.2 & 17.1 & 16.8 & 16.6 & 19.3 & 18.9 & 19.5 & 20.8 \\
\hline Asset Quality $^{2}$ & 38.2 & 39 & 37.7 & 33.4 & 28 & 24.8 & 20.2 & 10.7 & 9.2 & 7.9 & 6.3 \\
\hline Profitability ratio $^{3}$ & 0.5 & 1.7 & 1 & 2.2 & 2.1 & 2.4 & 2.8 & 3 & 2.8 & 2.9 & 3.6 \\
\hline Domestic Credit (\%) & -8.7 & 2.1 & 9 & 10.9 & 16.8 & 4.8 & 14.9 & 15.6 & 22.8 & 15.7 & 25.1 \\
\hline Private sector credit (\%) & -9.1 & -2.4 & 4.5 & 6.7 & 24.7 & 9.3 & 14.3 & 22.6 & 26.7 & 13.9 & 20.3 \\
\hline Liquidity ratio $^{4}$ & 43.1 & 45.1 & 43.4 & 48.2 & 45.5 & 41.7 & 41.8 & 44.8 & 46.4 & 46.3 & $51 \%$ \\
\hline
\end{tabular}

Source: Central Bank of Kenya

(1) Measured as a ratio of total regulatory capital (tier 1 and 2) to total risk weighted assets, (2) Measured as a ratio of total non-performing loans to total loans, (3) Measured as a ratio of annualized profit after tax to average assets, (4) Measured as ratio of total liquid assets to net deposit liabilities. 
Table 2. Regression Results for Fixed Effects and Random Effects Models

\begin{tabular}{|c|c|c|c|c|c|c|c|c|}
\hline & \multicolumn{4}{|c|}{ Fixed Effects } & \multicolumn{3}{|c|}{ Random Effects } & \multirow{2}{*}{$\begin{array}{l}\text { GMM } \\
\text { Model } 4 \\
\end{array}$} \\
\hline & Model1 & Model 2 & Model 3 & Model 3a & Model 1 & Model 2 & Model 3 & \\
\hline Constant & $\begin{array}{l}8.08 \\
(16.0)^{* * *}\end{array}$ & $\begin{array}{l}9.88 \\
(11.4)^{* * *}\end{array}$ & $\begin{array}{l}9.45 \\
(15.6)^{* * *}\end{array}$ & $\begin{array}{l}9.67 \\
(39)^{* * *}\end{array}$ & $\begin{array}{l}7.96 \\
(9.34)^{* * *}\end{array}$ & $\begin{array}{l}9.92 \\
(9.6)^{* * *}\end{array}$ & $\begin{array}{l}9.5 \\
(10.9)^{* * *}\end{array}$ & \\
\hline Credit & $\begin{array}{l}0.30 \\
(6.32)^{* * *}\end{array}$ & $\begin{array}{l}0.19 \\
(3.35)^{* * *}\end{array}$ & $\begin{array}{l}0.20 \\
(5.35)^{* * *}\end{array}$ & $\begin{array}{l}0.19 \\
(11.4)^{* * *}\end{array}$ & $\begin{array}{l}0.31 \\
(7.68)^{* * *}\end{array}$ & $\begin{array}{l}0.19 \\
(3.4)^{* * * *}\end{array}$ & $\begin{array}{l}0.20 \\
( \\
7.14)^{* * *}\end{array}$ & $\begin{array}{l}0.04 \\
(3.31)^{* * *}\end{array}$ \\
\hline Labour & & $\begin{array}{l}0.24 \\
(1.77)^{*}\end{array}$ & $\begin{array}{l}0.12 \\
(1.0)\end{array}$ & $\begin{array}{l}0.13 \\
(4.1)^{* * *}\end{array}$ & & $\begin{array}{l}0.25 \\
(2.17)^{* *}\end{array}$ & $\begin{array}{l}0.14 \\
(1.22)\end{array}$ & $\begin{array}{l}0.02 \\
(1.07)\end{array}$ \\
\hline Interest rate & & & $\begin{array}{l}-1.12 \\
(-4.8)^{* * *}\end{array}$ & $\begin{array}{l}-0.81 \\
(-5.8)^{* * *}\end{array}$ & & & $\begin{array}{l}-1.08 \\
(-5.22)^{* * *}\end{array}$ & \\
\hline Lagged dependent var. & & & & & & & & $\begin{array}{l}0.98 \\
(30.6)^{* * *}\end{array}$ \\
\hline \multicolumn{9}{|l|}{ Fixed Effects: } \\
\hline Agriculture & 1.44 & 1.07 & 1.28 & 1.26 & & & & \\
\hline $\mathrm{B} \& \mathrm{C}$ & -0.59 & -0.61 & -0.58 & -0.58 & & & & \\
\hline $\mathrm{E} \& W$ & -0.22 & 0.28 & -0.04 & -0.05 & & & & \\
\hline Manu. & 0.27 & 0.06 & 0.22 & 0.23 & & & & \\
\hline M\&Q & -1.92 & -1.57 & -1.81 & -1.81 & & & & \\
\hline $\mathrm{T} \& \mathrm{C}$ & 0.61 & 0.54 & 0.59 & 0.59 & & & & \\
\hline WHR & 0.40 & 0.21 & 0.35 & 0.36 & & & & \\
\hline Adjusted R-Squared & 0.97 & 0.98 & 0.99 & 0.99 & 0.33 & 0.48 & 0.60 & \\
\hline Redundant Fixed Effects F-test stat. & $\begin{array}{l}395 \\
(0.00)\end{array}$ & $\begin{array}{l}338 \\
(0.00)\end{array}$ & $\begin{array}{l}462 \\
(0.00)\end{array}$ & $\begin{array}{l}5949 \\
(0.00)\end{array}$ & & & & \\
\hline Sargan test $\left(\mathrm{Chi}^{2}\right.$ & Statistic) & & & & & & & $\begin{array}{l}74.3 \\
(0.251)\end{array}$ \\
\hline
\end{tabular}

$* * * * *$ significant at $1 \%, \quad 5 \%$ and $10 \%$ significance levels respectively. $t$ values for the coefficients in brackets. P-values for fixed effects F-test and Sargan test statistics in brackets. $\mathrm{B} \& \mathrm{C}=$ Building and Construction; $\mathrm{E} \& \mathrm{~W}=$ Electricity and Water; Manu. $=\mathrm{Manufacturing} ; \mathrm{M} \& \mathrm{Q}=$ Mining and Quarrying; T\&C $=$ Transport and Communication; WHR=Wholesale and Retail Trade and, Hotels and Restaurants. 
Table 3. Two way component models (fixed and random)

\begin{tabular}{|c|c|c|}
\hline & Fixed & Random \\
\hline & Model 2 & Model 2 \\
\hline \multirow[t]{2}{*}{ Constant } & 10.5 & 10.3 \\
\hline & $(22.1)^{* * *}$ & $(19.3)^{* * *}$ \\
\hline \multirow[t]{2}{*}{ Credit } & 0.07 & 0.10 \\
\hline & $(2.3)^{* *}$ & $(3.79)^{* * *}$ \\
\hline \multirow[t]{2}{*}{ Labour } & 0.06 & 0.11 \\
\hline & $(1.8)^{*}$ & $(1.5)^{*}$ \\
\hline \multicolumn{3}{|c|}{ Fixed Effects (cross section): } \\
\hline Agriculture & 1.44 & \\
\hline $\mathrm{B} \& \mathrm{C}$ & -0.52 & \\
\hline $\mathrm{E} \& \mathrm{~W}$ & -0.48 & \\
\hline Manu. & 0.48 & \\
\hline M\&Q & -2.14 & \\
\hline $\mathrm{T} \& \mathrm{C}$ & 0.65 & \\
\hline WHR & 0.57 & \\
\hline \multicolumn{3}{|l|}{ Fixed Effects period } \\
\hline 1998 & -0.18 & \\
\hline 1999 & -0.17 & \\
\hline 2000 & -0.18 & \\
\hline 2001 & -0.12 & \\
\hline 2002 & -0.10 & \\
\hline 2003 & -0.05 & \\
\hline 2004 & -0.01 & \\
\hline 2005 & 0.03 & \\
\hline 2006 & 0.08 & \\
\hline 2007 & 0.14 & \\
\hline 2008 & 0.14 & \\
\hline 2009 & 0.18 & \\
\hline 2010 & 0.24 & \\
\hline Adjusted R-Squared & 0.99 & 0.24 \\
\hline
\end{tabular}

$* * * * *$ significant at $1 \%, 5 \%$ and $10 \%$ significance levels respectively. $\mathrm{t}$ values for the coefficients in brackets. $\mathrm{B} \& \mathrm{C}=\mathrm{Building}$ and Construction; $\mathrm{E} \& \mathrm{~W}=$ Electricity and Water; Manu. = Manufacturing; $\mathrm{M} \& \mathrm{Q}=$ Mining and Quarrying; $\mathrm{T} \& \mathrm{C}=$ Transport and Communication; WHR=Wholesale and Retail Trade and, Hotels and Restaurants.

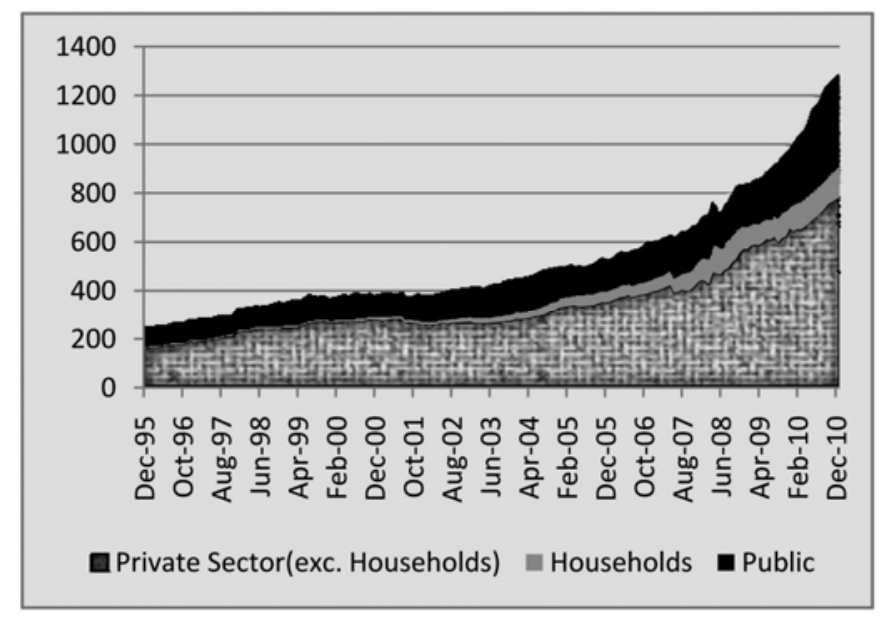

Figure 1. Composition of Credit between public and private sector 